\title{
Effect of Contextual Teaching Learning Model on Motivation and Learning Outcomes in Civic Education Learning in Junior High School
}

\author{
Vinna Dinda Kemala ${ }^{1}$ and Mukhamad Murdiono ${ }^{2}$ \\ ${ }^{1}$ Postgraduate Student, Yogyakarta State University, Indonesia \\ ${ }^{2}$ Doctor, Associate Professor, Department Of Civic Education, Yogyakarta State University, \\ Indonesia \\ 1vinnadindakemala@gmail.com, 2mukhamad murdiono@uny.ac.id
}

\begin{abstract}
The learning model has become the latest issue in Civic Education. This study analyzes the Contextual Teaching and Learning (CTL) learning model to improve students' motivation and learning outcomes in civic education learning. The CTL learning model aims to make students more able to solve a variety of real problems both in lessons and problems that exist outside of school. The research method uses a quantitative approach. The quasi-experimental method was used in a pretest and posttest design group. This research uses random sampling. Then the subject of this study was 34 students in SMP Negeri 6 Yogyakarta. The results of this study indicate that the CTL learning model on the civic education learning of Pancasila values as a basis for the country and the nation's life outlook significantly influences the motivation and learning outcomes of students. Also, the CTL learning model can improve learning outcomes in the medium category.
\end{abstract}

Keywords: CTL, learning motivation, learning outcomes, civic education

\section{INTRODUCTION}

Education is a dynamic manifestation of human art and culture for its developmental requirements. It is these developments and changes that are supposed to work with a changing culture of life. Education is a very strategic situation to improve the quality of the Human Resources (HR) of the Indonesian state and includes professional aspects, knowledge, and abilities by linking the demands of the development of the nation. The aim of education is expected to be to guide and deliver students to changes in student development, such as; student behavior, intellectual, and morals in the social environment of students. The success of achieving these goals is measured by students' mastery of the information conveyed by the teacher. Teachers are expected to be able to guide and guide students because education rests on the process of active learning or the participation of teachers and students in the teaching and learning process.

One of the realizations of the objectives of national education is through learning Civic Education. National education based on Pancasila aims to improve the quality of Indonesian people, namely people who have faith and are devoted to God Almighty, virtuous character, personality, discipline, working hard, tough, responsible, independent, intelligent, smart, 
skilled, and physically and mentally healthy. Civic Education in accordance with the contents of the 2006 Curriculum is education about values whose targets are not merely the transfer of knowledge but are more emphasized on the formation of attitudes [1].

The purpose of Civic Education in schools is more emphasized on the mastery of knowledge and skills that can provide students with provisions in facing daily life [2]. According to Johnson \& Morris, the main role of citizenship and Citizenship Education in the country is related to the process of state formation and is designed to build a shared identity instilling patriotism and loyalty to the nation [3]. In the process of learning Citizenship Education requires active activities, so that students can develop their thinking patterns so that they can think critically and rationally so that the results of their learning will develop in a better direction.

Factors that influence learning outcomes are factors experienced by students such as learning attitudes, motivation, concentration, self-confidence, intelligence, learning ideals and learning habits. These factors are internal factors, while external factors are factors that influence learning activities such as teachers, facilities and infrastructure, environment and school curriculum [4]. The success of Civic Education learning in schools depends on the way teachers teach in class, regarding the professional skills of Civic Education teachers so far, there are still many Civic Education teachers in teaching using conventional methods or lecture methods with an emphasis on students' ability to memorize [5].

Learning motivation of students in SMP 6 Yogyakarta in the author's view is still very lacking or weak. This is due to the lack of encouragement and attention from the teachers at the school. Facts in the field, many students are outside the room during class hours, many students do not collect assignments, do not wholeheartedly, and sleep during class hours. To increase student activity, appropriate learning models need to be developed to convey various concepts in learning that provide opportunities for students to exchange opinions, work together, interact with teachers and respond to the thoughts of other students.

The application of various learning methods or models seeks to increase the success of students in learning and at the same time as one indicator of improving the quality of education. The Contextual Teachings and Learning (CTL) learning model is an effective and efficient learning model as an alternative. According to Rahman et al who stated that the CTL learning model can improve the quality of learning and the development of critical thinking skills as good citizens in social science learning, in the CTL learning model the teacher and school become an integration of character education with a contextual approach [6].

From the results of research conducted by Suhartono with the title 'Changing the Textual Learning Pattern of Textual to Contextual Pattern (CTL)', concluded that contextual learning can connect material with the context of everyday life in finding meaning in life and very suitable to be applied in citizenship learning that has the competence to prepare students to become good citizens in the life of society, nation and state [7]. This is in line with research conducted by Setyati with the title 'The Effectiveness of the Implementation of the Contextual Teaching And Learning (CTL) Model and Cooperative Learning Model in Improving Student Learning Outcomes in Pkn Lessons in State Junior High School 2 Jeruklegi Cilacap Regency', the study concluded that the CTL learning model is more effective than the Cooperative Learning model in improving student learning outcomes in Civics Learning in SMP Negeri 2 Jeruklegi Cilacap district [8]. Not much different, the results of Darmawati's research entitled 'The CTL Model in Learning Citizenship-Based Citizenship Education' shows that efforts to embed national character values in Civics learning are given through a cooperative approach, while the type for the type is adapted with the subject matter approach analyzed by teachers and focused on the use of cooperative models with predominantly CTL model types. Thus 
creating classrooms in which students become active participants and responsible for learning [9].

After the background has been explained, the author wants to find out how the contribution of the CTL learning model and learning motivation towards the learning outcomes of students with the title of research 'The Effect of Contextual Teaching Learning Model (CTL) on Motivation and Learning Outcomes of Civic Education in Junior High School'. This learning model is expected to be able to involve students in the whole learning process and can involve all aspects, namely cognitive, affective, and psychomotor, as well as physically and mentally involving all parties in learning so that students have freedom of thought, opinion, active and creative.

\section{METHOD}

The method for measuring learning motivation uses a quantitative approach with quasiexperimental methods. Meanwhile, learning outcomes are measured by the quasi-experimental method. The experimental design used was quasi-experimental with one pretest-posttest design group. This research was conducted in Yogyakarta 6 Public Middle School, using 34 students of class VIII as subjects. This research uses purposive random sampling.

Explanation:

$$
<g \geq \frac{(\text { Spost }- \text { Spre })}{100-\text { pre }}
$$

$<$ g $>=$ gain normalized

Spost $=$ score posttest

Spre $=$ score pretest

Subsequently interpretation is presented in Table 1.

Table 1. Classification of N-Gain Interpretations

\begin{tabular}{|c|c|}
\hline Substantial Percentage & Interpretation \\
\hline $\mathrm{g} \geq \mathbf{0 , 7}$ & High \\
\hline $\mathbf{0 , 3} \leq \mathbf{g}<\mathbf{0 , 7}$ & Medium \\
\hline $\mathbf{g}<\mathbf{0 , 3}$ & Low \\
\hline
\end{tabular}

\section{Result and Discussion}

\subsection{Result}

\subsubsection{Student Motivation Data}

Tabel 2. Paired Samples Statistics

\begin{tabular}{|c|c|c|c|c|}
\hline \multirow{2}{*}{ Pair 1 Sesudah perlakuan } & Mean & N & $\begin{array}{c}\text { Std. } \\
\text { Deviasion }\end{array}$ & $\begin{array}{c}\text { Std. Error } \\
\text { Mean }\end{array}$ \\
\cline { 2 - 5 } & 101,91 & 34 & 14,919 & 2,559 \\
\cline { 2 - 5 } Sebelum Perlakuan & 98,82 & 34 & 17,497 & 3,001 \\
\hline
\end{tabular}

Tabel 3. Paired Samples Correlations

\begin{tabular}{|c|c|c|c|}
\hline & N & Correlation & Sig \\
\hline \begin{tabular}{c} 
Pair 1 $\begin{array}{c}\text { Sesudah Perlakuan }- \\
\text { Sebelum perlakuan }\end{array}$ \\
\hline
\end{tabular} & 34 & .379 & .027 \\
\hline
\end{tabular}


Tabel 4. Paired Samples Test

\begin{tabular}{|c|c|c|c|c|c|c|c|c|}
\hline & \multicolumn{5}{|c|}{ Paired Differences } & \multirow{3}{*}{$\mathbf{t}$} & \multirow{3}{*}{ Df } & \multirow{3}{*}{$\begin{array}{l}\text { Sig. } \\
(2- \\
\text { tailed })\end{array}$} \\
\hline & \multirow[t]{2}{*}{ Mean } & \multirow[t]{2}{*}{$\begin{array}{c}\text { Std. } \\
\text { Deviation }\end{array}$} & \multirow[t]{2}{*}{$\begin{array}{l}\text { Std. } \\
\text { Error } \\
\text { Mean }\end{array}$} & \multicolumn{2}{|c|}{$\begin{array}{c}95 \% \\
\text { Confidence } \\
\text { Interval of the } \\
\text { Differences } \\
\end{array}$} & & & \\
\hline & & & & Lower & Upper & & & \\
\hline $\begin{array}{cl}\text { Pair } 1 & \text { Sesudah } \\
& \text { Pelakuan- } \\
& \text { Sebelum } \\
& \text { Perlakuan }\end{array}$ & 3.088 & 18.187 & 3.119 & -3.257 & 9.434 & .990 & 33 & .329 \\
\hline
\end{tabular}

- Output Paired Samples Statistics shows the mean after treatment 101.91 and the mean before treatment 98.82, while $\mathrm{N}$ for each cell is 34 . While the Standard Deviation for after treatment is 14,919 , and the standard deviation before treatment is 17,497. The mean standard error for after treatment was 2,559, whereas before treatment was 3,001.

- Paired Samples Correlation output shows the magnitude of the correlation between the two samples, in which both the correlation figures are 0.379 and the significance level is 0.027 . Decision making is based on the results of the probabilities obtained, namely:

a. If the probability is $>0.05$ then the null hypothesis is accepted.

b. If the probability is $<0.05$ then the null hypothesis is rejected.

The magnitude of the significant value of 0.027 is far greater than 0.05 . This means the hypothesis that states there is a relationship between after implementation and before implementation, in other words between after implementation and before implementation does not have a significant relationship.

- Output Paired Sample Test displays the results of a comparative analysis using the ttest. The output shows the mean after implementation and before implementation is 3.008 , the standard deviation is 18,817 , the mean standard error is 3.119 . The lowest difference is both $-3,257$, while the highest difference is 9,434. Test results t-test $=$ 0.990 with $\mathrm{df}=33$ and significance 0.329 . Interpretation of t 0 can be done by:

a. By referring to the t-test value by comparing t0 ( $t$ observation) with $t$ ( $t$ table), where the $\mathrm{df}=33$ number is obtained: 2.03 for the significant level of $5 \%$ and 2.74 for the significant level of $1 \%$. With $0=0.990$ means greater than $t$ (mathematical sign - (minus) in this case is ignored) at a significant level of $1 \%$ $(2.03>0.990<2.74)$ which means that the null hypothesis is accepted.

b. By referring to the amount of significance. In this case, the decision is taken with the provisions,

If the probability is $>0.05$ then the null hypothesis is accepted

If the probability is $<0.05$ then the null hypothesis is rejected

With a significance value of 0.027 means greater than 0.05 , it means a null hypothesis which states that there are differences after treatment and before treatment is received.

There is a significant difference between after treatment and before treatment. The difference in mean shows that after treatment is better than before treatment. 


\subsubsection{Data on student learning outcomes}

Tabel 5.

\begin{tabular}{|c|c|c|}
\hline \multirow{2}{*}{ Data Source } & \multicolumn{2}{|c|}{ Class } \\
\cline { 2 - 3 } & Pretest & Posttes \\
\hline Min & 30 & 70 \\
\hline Max & 60 & 85 \\
\hline Mean & 42,00 & 73,82 \\
\hline Median & 40,00 & 75,00 \\
\hline
\end{tabular}

The score of learning outcomes using the CTL learning model in table 5 is quite high. The mean pretest score was 42.00 while the posttest score was 73.82 . Test results after treatment using the CTL learning model have an average score higher than before treatment.

\subsubsection{Increasing the value of student learning outcomes on the values of Pancasila as the State Basis and Nation's Life View}

Improved student learning outcomes are calculated through the average value of the class using the calculation formula n-gain. The results of the pretest and posttest conducted to 34 students as research subjects to analyze the improvement of learning outcomes on the material values of Pancasila as the basis of the country and the nation's life outlook can be seen in Table 6.

Tabel 6. $N$-gain Data

\begin{tabular}{|c|c|c|}
\hline Number of Samples & N-gain Average & Classification \\
\hline 34 & 0,542 & Medium \\
\hline
\end{tabular}

Table 6 , shows that the $n$-gain value is 0.542 medium category. This means that the CTL learning model significantly influences student learning outcomes.

\subsection{Discussion}

3.2.1 The Effect of Contextual Teaching Learning Model on Motivation and Learning Outcomes in Civic Education Learning in Junior High School

In implementing learning, a model is needed for the achievement of such learning. The learning model includes information, thinking skills, ideas, and also appreciates these ideas. There are many models chosen by teachers in implementing learning, such as PPKn learning, teachers can use the Contextual Teaching and Learning (CTL) learning model. The CTL learning model is identified as a promising model and actively engages students and promotes improved learning and skills development. The CTL learning model has been defined in different ways, based on the intentions of groups who fight for its use [10].

One form of contextualization is basic skills such as reading and writing. It is also used in the field of teaching discipline without focusing on basic skills. The teacher presents authentic practices related to topics taught to deepen domain knowledge. Problem-based learning contextualizes learning content in real-life situations [11]. The contextualization model shows that it is more effective and works better for students who previously had a fair second level of language knowledge. In a contextual approach, the role of students is life and death. Students are persuaded to use language creatively and collaboratively. In creating an 
extraordinary atmosphere for learning the teacher emphasizes several models such as making teaching objectives clarified, emphasizing their own chosen models for the use of language in and outside the classroom [12].

Contextualization has extraordinary depth and influence on various language skills of students. In the field of language learning and teaching, contextualization occurs through bridging ideas and concepts across courses. The contextual curriculum helps students learn language skills by teaching skills using authentic contexts where students must use those skills in the real world [13]. Contextualization has also been used in teacher education. Where the aim is to prepare pre-service teachers to integrate literacy into teaching content fields and motivate and enhance their feelings and sensitivity related to learners' real and real-life situations [14].

In the learning process, the teacher is an important component of learning. Teachers in the context of learning have a large and strategic role. Teachers who are directly dealing with students to transfer science and technology while educating with positive values through guidance and example. The teacher is very influential in motivating to learn. Motivation provides a definition, motivation as a series of efforts to provide certain conditions so that someone wants and wants to do something, and if he does not like it, it will try to negate or avoid the feeling of dislike [15].

During the learning process that uses the CTL model, the teacher links the material to be taught the real-world situation of students, and encourages students to make connections between the knowledge they have and their application in daily life [16]. The impact of the CTL learning model on students, namely: 1) students will understand that all the actions carried out will affect others, help communicate with others. 2) develop each individual student, pay attention, motivate and encourage each student, and students will respect their peers and adults. 3) achieving high standards, identifying clear goals and motivating students to achieve them, as well as showing them ways to achieve success.

In implementing the CTL learning model there are several stages, as follows: 1) the invitation stage, students are encouraged to use the initial knowledge about the concepts discussed, 2) the exploration stage, students are given the opportunity to investigate and find concepts through the collection, organization, interpretation of data in a discussion activity about the problem discussed, 3) the explanation and solution stages, students provide an explanation based on the results of observation along with reinforcement from the teacher, and 4) the stage of taking action, students can make decisions, use knowledge or skills, information or ideas, submit follow-up questions, make suggestions individually or in groups related to problem-solving [16].

The researcher applies the learning model to the PPKn learning of Pancasila values as a basis for the nation and the nation's life outlook. Improving the ability to understand the meaning and linkages of the Pancasila precepts in understanding the Pancasila as a whole through the CTL model, so students are trained to be more active and appreciate their role in the CTL game. In addition, students are trained to discuss with the group and work together to improve each other's role in the game. As for increasing students' motivation in learning PPKn on the values of Pancasila values, researchers provide rewards to reward successful students [17] [18]

\section{REFERENCES:}


[1]. S. Andayani. "Meningkatkan Hasil Belajar Siswa Melalui Penerapan Model Pembelajaran Tai (Team Assisted Individualization) Pada Mata Pelajaran Pkn Kelas Iv Sdn Gadingrejo 01 Kecamatan Umbulsari Kabupaten Jember". Pancaran Pendidikan, Vol. 4, No. 4, 2015

[2]. R. Rachmadtullah. P. A Wardani. "Peningkatan Hasil Belajar Pendidikan Kewarganegaraan Melalui Metode Pembelajaran Contexstual And Learning". Jurnal Pendidikan Dasar, Vol. 7, No. 1,2016

[3]. L. Johnson. P. Morris. "Towards A Framework For Critical Citizenship Education". The Curriculum Journal. Vol. 21, No. 1, 2010

[4]. R. Silalahi. "Kontribusi Model Pembelajaran Kontekstual Tipe Inkuiri Dalam Meningkatkan Motivasi Dan Prestasi Belajar Siswa Pada Mata Pelajaran Pendidikan Kewarganegaraan”. Edisi Khusus, Vol. 2, 2011

[5]. A. Agustinah, I. Suntoro. Y, Nurmalisa. "Pengaruh Motivasi Dan Disiplin Belajar Terhadap Prestasi Belajar Siswa". Jurnal Kultur Demokrasi, Vol. 1, No. 4. 2013

[6]. H. Rahman. S. B. Thalib. A. Mahmud. "Integrated Character Education In Social Sciences With Contextual Teaching And Learning Approach". The New Educational, Vol. 48, No. 4, 2017

[7]. E. Suhartono. "Perubahan pola pembelajaran PKn yang tekstual ke pola kontekstual (CTL)". JTP2IPS. Vol, 3. No. 1, 2018

[8]. D. S. Setyati. "Keefektifan Penerapan Model Contectual Teaching And Learning (CTL) Dan Model Cooperative Learning Dalam Meningkatkan Hasil Belajar Siswa Pada Pelajaran Pkn Di Smp Negeri 2 Jeruklegi Kabupaten Cilacap". Probisnis, Vol. 6, No. 1, 2013

[9]. T. Darmawati. D. Darsono. "Model CTL Dalam Pembelajaran Pendidikan Kewarganegaraan Berbasis Karakter Bangsa". Jurnal Studi Sosial, Vol. 3, No. 4, 2015

[10]. E.D. Baker. L. Hope. K. Karandjeff. "Contextualized Teaching \& Learning: A Faculty Primer". California: Spring. 2009

[11]. D. Perin. "Facilitating Student Learning Through Contextualization". Ccrc Working Paper No.29. Teachers College: Columbia University. 2011

[12]. Moghaddas, B. "The Effect Of Contextualization On The Iranian Efllearners Performance In Reading Tasks". Ijesr, Vol. 3, No. 2, 2013

[13]. J. L. Utech. "Contextualized curriculum for workplace education an introductory guide". Massachusetts Department of Elementary And Secondary Education Adult and Community Learning Services. 2008

[14]. D. Perin. M. Crocco. A. Marri. J. Ricci. A. Rivet. B. Chase. "Integrating literacy in content classrooms". Academic Exchange Quarterly. Vol. 1, No. 32, 2009

[15]. A.M. Sadirman. "Interaksi dan Motivas Belajar mengajar". Raja Grafindo: Jakarta. 2011

[16]. J.J. Arifin. "Implementasi Model Pembelajaran Contextual Teaching And Learning (CTL) Untuk Meningkatkan Hasil Belajar Pkn Siswa Kelas IV SDN 001 Tandun Tahun Pelajaran 2017/2017'. Edu Research. Vol. 7, No. 2, 2018

[17]. B. Tampubolon. "Penerapan Pendekatan Kontekstual Untuk Meningkatkan Hasil Belajar Pendidikan Kewarganegaraan Siswa Kelas IV SD”. Jurnal Pendidikan Dan Pembelajaran, Vol. 2, No. 9, 2013

[18]. K. Saddhono, A. Hasibuan, and M. I. Bakhtiar, "Facebook as A Learning Media in TISOL (Teaching Indonesian to Speakers of Other Languages) Learning to Support The Independency of Foreign Students in Indonesia," in Journal of Physics: Conference Series, 2019, vol. 1254, no. 1, p. 12061. 